\title{
PERUMUSAN PORTOFOLIO DINAMIS CRYPTOCURRENCY DENGAN SAHAM-SAHAM LQ45
}

\author{
Anggreini Pamilangan ${ }^{1}$, Robiyanto Robiyanto ${ }^{2}$ \\ ${ }^{1,2}$ Fakultas Ekonomika dan Bisnis, Universitas Kristen Satya Wacana \\ Indonesia \\ e-mail: 212016036@student.uksw.edu1, robiyanto@staff.uksw.edu²
}

\begin{abstract}
Abstrak
Penelitian ini bertujuan untuk menganalisis kinerja portofolio yang dibentuk antara cryptocurrency dengan indeks LQ45 apakah memiliki kinerja yang lebih baik daripada portofolio yang hanya dibentuk dari indeks LQ45 saja. Jenis data yang digunakan dalam penelitian ini yaitu data sekunder berupa time series dengan periode penelitian Juni 2016 sampai Juni 2019. Data dalam penelitian ini berupa data kuantitatif. Hasil penelitian menunjukkan bahwa cryptocurrency memiliki korelasi negatif dengan indeks LQ45 sehingga dapat dijadikan sebagai aset lindung nilai. Pengukuran kinerja portofolio diukur berdasarkan Sharpe index, Treynor index, Jensen index dan Sortino ratio. Secara singkat, hasil dari pengukuran kinerja portofolio dapat disimpulkan bahwa dengan melibatkan cryptocurrency ke dalam pembentukan portofolio akan menghasilkan kinerja portofolio yang lebih baik.
\end{abstract}

Kata kunci : Portofolio, Lindung Nilai, Cryptocurrency , Indeks LQ45, DCCGARCH.

\begin{abstract}
This study aims to analyze the performance of portfolios formed between cryptocurrency with the LQ45 index whether it has better performance than portfolios that are only formed from the LQ45 index. The type of data used in this study is secondary data in the form of time series with the study period from June 2016 to June 2019. The data in this study are quantitative. The results showed that cryptocurrency has a negative correlation with the LQ45 index so it can be used as a hedging asset. Portfolio performance measurement is measured based on the Sharpe index, Treynor index, Jensen index, and Sortino ratio. In brief, the results of portfolio performance measurement can be concluded that by involving cryptocurrency in the formation of a portfolio will produce a better portfolio performance.
\end{abstract}

Keywords : Portfolio, Hedge, Cryptocurrency, LQ45 Index, DCC-GARCH. 


\section{PENDAHULUAN}

Menuju perekonomian yang semakin modern, peran investasi semakin penting baik untuk jangka pendek maupun jangka panjang dengan harapan mendapatkan keuntungan dengan tingkat pengembalian yang tinggi dari hasil investasi tersebut. Tingkat pengembalian dan risiko sangat penting bagi para investor dalam memaksimalkan kekayaan dan salah satu cara yang dapat dilakukan yaitu dengan menentukan jenis investasi yang layak dan pemilihan portofolio yang memiliki kinerja lebih baik (Markowitz, 1952).

Teori portofolio mulai diperkenalkan Markowitz (1952) yang menyatakan bahwa keberhasilan dari investasi dapat dilihat dari return yang dihasilkan dan hal inilah yang menjadi pertimbangan investor dalam berinvestasi. Portofolio dapat dinyatakan sebagai sekumpulan aset dengan tujuan ekonomis tertentu dengan konsep dasar bagaimana mengalokasikan sejumlah dana pada berbagai jenis investasi dengan keuntungan optimal dengan tingkat risiko yang kecil (Eko, 2008; Bierman, 1998). Risiko dalam hal ini dapat diartikan sebagai kemungkinan return aktual tidak sesuai dengan return yang diharapkan (Tandelilin, 2001; Husnan, 2003; Chandra dan Hapsari, 2012).

Berdasarkan teori risiko dan tingkat pengembalian, investor dapat melakukan diversifikasi atau penyebaran investasi yang mampu mengurangi risiko dengan tetap mendapat return yang diharapkan (Puspitasari dan Pramesti, 2011). Dalam meminimalkan risiko investasi para investor dapat membentuk portofolio dengan melakukan berbagai bentuk investasi sehingga risiko kerugian pada satu jenis investasi dapat ditutup dengan keuntungan pada jenis investasi yang lain. Diversifikasi bertujuan untuk meminimalkan risiko yang tidak dapat dihilangkan.

Salah satu dasar pembentukan portofolio yang sering digunakan adalah indeks LQ45 (Hartono, 2010). Indeks LQ45 merupakan indeks yang memiliki tingkat likuid kapitalisasi pasar dan transaksi perdagangan yang tinggi, jika dibandingkan dengan jenis investasi yang lain, indeks LQ45 memiliki risiko yang rendah dengan kinerja yang baik serta fluktuasi harga cenderung kecil sehingga return yang didapatkan tidak setinggi dengan indeks lain yang memiliki fluktuasi harga yang signifikan (Chandra dan Hapsari, 2012). Dalam penelitian Oktaviani dan Wijayanto (2016) ia memilih indeks LQ45 dalam membentuk portofolio karena perusahaan tersebut termasuk perusahaan yang memiliki kinerja yang baik dengan likuiditas yang tinggi dan mudah diperjualbelikan sehingga dapat membentuk portofolio optimal sesuai dengan tingkat pengembalian yang diharapkan dan risiko yang kecil. Dahlan et al., (2012) dan Wibowo (2014) juga melakukan penelitian mengenai pembentukan portofolio dengan tujuan untuk mengetahui bahwa indeks LQ45 merupakan portofolio optimal dengan melihat besarnya proporsi dana yang terdapat pada indeks LQ45 dan besarnya expected return serta risiko portofolio yang telah terbentuk. Rini et al., (2012) juga melakukan evaluasi terhadap portofolio indeks LQ45, ia mengemukakan bahwa indeks LQ45 merupakan perusahaan dengan likuiditas tinggi dan perlu melakukan kombinasi dengan investasi yang lain agar menghasilkan kinerja portofolio yang positif.

Pembentukan portofolio tidak hanya dibentuk dari indeks LQ45 saja tetapi dapat juga dibentuk dengan portofolio lintas aset lainnya. Beberapa studi sebelumnya telah menjabarkan mengenai kinerja portofolio dan efektivitas lindung nilai diantaranya Prihanto et al.,(2018); Robiyanto et al.,(2019); Hartono (2010); Yuniarti (2010); Priyatna dan Sukono (2003). Penelitian tersebut berfokus pada pembentukan portofolio seperti logam mulia, obligasi dan saham, sehingga yang akan membedakan penelitian ini dengan penelitian sebelumnya adalah pembentukan portofolio dinamis antara cryptocurrency yang terdiri dari bitcoin dan ethereum serta indeks LQ45.

Indeks LQ45 dengan cryptocurrency memiliki kelas aset yang berbeda. Setiap kelas aset diharapkan mampu mencerminkan risiko dan tingkat pengembalian investasi serta kinerja yang berbeda dalam lingkungan pasar tertentu. Kelas aset yang berbeda memiliki tingkat resiko yang berbeda mampu mengurangi risiko investasi dan hal inilah yang menjadi pertimbangan investor saat ini untuk membentuk diversifikasi portofolio (Hernendi, 2019), selain itu perkembangan teknologi yang semakin maju memberi dampak terhadap pengelolaan sistem keuangan serta berbagai fasilitas keuangan yang semakin canggih dan banyak bermunculan. Masyarakat telah dipicu untuk menggunakan berbagai fasilitas teknologi yang tersedia termasuk masyarakat Indonesia. Sistem digital keuangan (cryptocurrency) seperti bitcoin dan ethereum telah menarik perhatian masyarakat Indonesia dalam menciptakan marketplace karena penggunaan yang lebih mudah dan cepat diakses secara online.

Dyhrberg (2016); Pal dan Mitra (2019); Bouri et al.,(2017); Mensi et al.,(2019) telah menjabarkan bahwa efektivitas bitcoin dapat dijadikan sebagai lindung nilai atau safe haven 
terhadap aset lainnya. Katsiampa (2018); Mensi et al.,(2019); Guo et al.,(2019) juga menunjukkan cryptocurrency dalam hal ini ethereum juga dapat dijadikan sebagai lindung nilai yang efektif dan Beneki et al., (2019) menunjukkan bahwa pada kondisi tertentu ethereum dapat dijadikan sebagai lindung nilai aset sesuai dengan kondisi permintaan di pasar.

Dengan demikian penelitian ini akan mengkaji kinerja portofolio antar saham LQ45 dan cryptocurrency yang terdiri dari bitcoin dan ethereum. Berdasarkan fenomena dan research gap maka persoalan yang akan dikaji yaitu apakah portofolio yang dibentuk dari cryptocurrency dengan indeks LQ45 memiliki kinerja yang lebih baik daripada portofolio saham-saham LQ45. Oleh karena itu, penelitian ini memiliki tujuan untuk menganalisis portofolio yang dibentuk dari cryptocurrency dengan indeks LQ45 memiliki kinerja yang lebih baik daripada portofolio yang hanya dibentuk dari saham-saham LQ45 saja. Untuk mengukur kinerja portofolio akan diukur berdasarkan Sharpe Index, Treynor Index, Jensen Index dan Sortino Ratio. Oleh karena itu, hasil dari penelitian ini diharapkan mampu memberi gambaran dan informasi tambahan bagi para pelaku di pasar bitcoin, ethereum dan sahamsaham LQ45 dalam memutuskan manajemen portofolio dan strategi lindung nilai dimasa yang akan dating.

\section{METODE}

Jenis data yang digunakan untuk penelitian ini yaitu data sekunder berupa time series atau biasa dikenal juga dengan data runtun waktu. Time series merupakan suatu rangkaian pengamatan dengan karakteristik kuantitatif dari satu atau lebih fenomena dalam periode waktu tertentu (Nugroho, 2011). Dalam penelitian ini, variabel yang digunakan adalah bitcoin, ethereum dan indeks LQ45. Data yang digunakan adalah data harian bitcoin dan ethereum serta data harga penutupan harian indeks LQ45. Periode pengamatan dari Juni 2016 sampai dengan Juni 2019. Alasan memilih periode tersebut dikarenakan pada tahun tersebut merupakan masa kejayaan penggunaan cryptocurency dan adanya Indodax yang merupakan bursa aset cryptocurrency telah mewadahi transaksi bitcoin dan ethereum di Indonesia. Sumber data diperoleh dari data Investing.

Penelitian ini menggunakan perumusan portofolio didasarkan pada dynamic conditional correlation. Perumusan portofolio dinamis diharapkan mampu menghasilkan tingkat pengembalian yang disesuaikan dengan risiko (risk-adjusted return) dari hedged portfolio akan jauh lebih baik jika dibandingkan dengan pengembalian yang disesuaikan dengan risiko (risk-adjusted return) dari unhedged portfolio, sehingga hipotesis yang digunakan dalam penelitian ini adalah :

H1 : Portofolio yang dibentuk dari cryptocurrency dengan indeks LQ45 memiliki kinerja yang lebih baik daripada portofolio indeks LQ45.

H1a : Portofolio yang dibentuk dari bitcoin dengan indeks LQ45 memiliki kinerja yang lebih baik daripada portofolio indeks LQ45.

H1b : Portofolio yang dibentuk dari ethereum dengan indeks LQ45 memiliki kinerja yang lebih baik daripada portofolio indeks LQ45.

\section{Teknik Analisis}

Berdasarkan penelitian yang telah dilakukan Prihanto et al., (2018) maka dalam penelitian ini perhitungan return dari variabel dirumuskan sebagai berikut :

\section{Indeks LQ45}

$$
\text { LQ45 }=\frac{\left[P \text { Indeks LQ45 }{ }^{-P} \text { Indeks LQ45 } t-1\right.}{\text { P Indeks LQ45 }}
$$

Dimana :

PLQ45,t : Harga penutupan harian indeks LQ45 pada waktu t

$P L_{4} 5_{,-1}$ : Harga penutupan harian indeks LQ45 pada waktu t-1

\section{Bitcoin}

$\mathrm{BTC}=\frac{\left[\text { Bitcoin }_{t}-P \text { Bitcoin }_{t-1}\right.}{P \text { Bitcoin }_{t-1}}$

Dimana :

P Bitcoin,, : Harga penutupan harian bitcoin pada waktu t

P Bitcoin,t-1 : Harga penutupan harian bitcoin pada waktu t-1

\section{Ethereum}

$\mathrm{ETH}=\frac{\left[\text { Ethereum }_{\mathrm{t}}-\text { E Etherewm }_{\mathrm{t}-1}\right.}{\text { PEthereum }}$

Dimana :

P Eth,t : Harga penutupan harian ethereum pada waktu t

P Eth,t-1 : Harga penutupan harian ethereum pada waktu t-1 
Model analisis yang digunakan untuk meneliti portofolio antara bitcoin, ethereum dan indeks LQ45 adalah DCC-GARCH (Dynamic Conditional Correlation-Generalized Autoregressive Conditional Heteroskedasticity) yang merupakan metode data runtun waktu (time series) yang digunakan untuk melihat apakah ada korelasi dinamis antara satu variabel dengan variabel lainnya dengan menggunakan program Eviews sehingga dalam penelitian ini untuk mengukur kinerja rasio hedging yang optimal dari berbagai estimasi GARCH diperlukan menghitung Hedging Effectivies (HE) (Prihanto et al., 2018; Pal dan Mitra, 2019; Arouri et al , 2012; Basher dan Sadorsky, 2015)

$\mathrm{HE}=\frac{\text { VarUnhed ged }- \text { Varhedged }}{\text { Varhed ged }}$

Dimana :

$$
\text { Warhedged }
$$

Var Unhedged: Variance indeks LQ45

Var Hedged : Variance portfolio cryptocurrency dan LQ45

Rumus Hedge Ratio dirumuskan sebagai berikut :

$\beta_{t}^{G s}=\frac{h_{t}^{S G}}{h_{t}^{G}}$

Dimana :

$\beta_{t}^{G s}:$ Hedge Ratio

$h_{t}^{S G}$ : Covariance cryptocurrency -LQ45 pada waktu t

$h_{t}^{G}$ : Conditional variance cryptocurrency pada waktu $t$

Menurut Prihanto et al., (2018); Pal dan Mitra, (2019) nilai $H E$ yang tinggi menunjukkan besarnya pengurangan risiko dalam portofolio dan akan menunjukkan efektivitas lindung nilai yang baik.

Risk adjusted return dari hedge portfolio dan unhedged portfolio dapat dilakukan dengan menggunakan Sharpe Index yang diperkenalkan Sharpe pada tahun 1996 yang dirumuskan sebagai berikut :

Risk Adjusted Return =

Average of Portfolio Return-Risk-Free Rate Portfolio Standard Deviation

Standar deviasi dari portofolio dirumuskan :

Standar Deviasi $(\sigma \mathrm{i})=\sqrt{\sum \frac{\left[\left(R_{\mathrm{i} i t-} E\left(R_{i-t}\right)\right]^{2}\right.}{N}}$
Perhitungan kinerja portofolio dapat diukur berdasarkan Sharpe Index, Treynor's Index, Jensen Index dan Sortino Ratio (Robiyanto et al., 2017; Angriana \& Robiyanto, 2018; Santosa dan Sjam, 2012; Tuerah, 2013; Ukhriyawati et al., 2017; Hartono, 2010) yang dirumuskan sebagai berikut:

\section{Adjusted Sharpe Index (ASI) =}

Sharpe Index $X \frac{\text { Number of Observations }(N)}{\text { Number of Observations }(N)+0.75}$

\section{Treynor's Index =}

$\frac{\text { Average of Portfolio Return - Risk Free Rate }}{\beta i}$

$\beta i=$ koefisien beta pasar

Jika nilai Treynor's Index positif dan semakin besar maka menunjukkan kinerja portofolio yang semakin baik.

Jensen Index $=R p-[R f+\beta p(R m-R f)]$

Dimana :

$\mathrm{Rp}=$ return portofolio pada waktu $\mathrm{t}$

$\mathrm{Rf}=$ return pada investasi bebas risiko pada waktu t

$\mathrm{Bp}=$ koefisien beta portofolio

$\mathrm{Rm}=$ return pasar

Pengukuran Jensen Index digunakan untuk mengukur apakah portofolio memiliki kinerja baik atau sebaliknya. Jika nilai Jensen Index positif semakin tinggi maka menunjukkan kinerja portofolio semakin baik.

\section{Sortino Ratio $($ SoM) $=$}

Average stock return-Risk Free Rate

$$
\sigma
$$

$\sigma=\sqrt{\frac{\sum(\min \mathrm{Rp} \text { MARO }) 2}{\mathrm{~N}-1}}$

Dimana :

$\begin{array}{ll}\sigma & : \text { Downside deviation } \\ \mathrm{Rp} & : \text { Stock return } \\ \mathrm{MAR} & : \text { Minimum Acceptable Return = risk- } \\ & \text { free rate } \\ \mathrm{N} & : \text { Number of observations }\end{array}$

Dengan ketentuan :

Jika (Rp-MAR) bernilai negatif, maka menggunakan nilai (Rp-MAR)

Jika (Rp-MAR) bernilai positif, maka menggunakan nilai 0 . 
Nilai rasio sortino semakin besar maka tingkat kerugian akan semakin kecil (Lakaba dan Robiyanto, 2018).

Untuk melihat adanya korelasi dinamis antara bitcoin, ethereum dan indeks LQ45, Winarno (2007); Prihanto et al., (2018) menggunakan model GARCH yang dinyatakan dalam persamaan sebagai berikut:

$$
Y t=\beta 0+\beta 1 X 1 t+\varepsilon t
$$$$
\sigma \mathrm{t} 2=\alpha 0+\alpha 1 \varepsilon t-12
$$

Berdasarkan fungsi tersebut, maka model ekonometrika yang diajukan dalam penelitian ini

$R_{i, t}=\sigma_{i}+\beta_{i} R_{m, t}+e_{i, t}$

Dimana :

Tabel 1. Analisis Statistik Deskriptif
$\mathrm{R}_{\mathrm{i}, \mathrm{t}}$ : $\quad$ Rata-rata return harian pada waktu $\mathrm{t}$

$\sigma_{i}: \quad$ Konstan

$\beta_{i} \quad$ Koefisien beta

$\mathrm{R}_{\mathrm{m}, \mathrm{t}} \quad$ Return portofolio harian pada waktu $\mathrm{t}$

$\mathrm{e}_{\mathrm{i}, \mathrm{t}} \quad$ Return residual yang tidak dijelaskan dari regresi pada waktu $t$

$E(i e, t)=0$

\section{HASIL DAN PEMBAHASAN}

Analisis Deskriptif Statistika

Berikut ini merupakan sajian dari hasil pengujian statistik deskriptif antara bitcoin, ethereum dan indeks LQ45. Analisis statistik deskriptif yang disajikan dalam tabel 1 merupakan statistik dasar yang meliputi minimum, maximum, average standar deviasi, beta dari bitcoin (BTC), ethereum (ETH), indeks LQ45 dan portofolio BTC-LQ45, ETH-LQ45.

\begin{tabular}{lccccc}
\hline & \multirow{2}{*}{ BTC } & \multirow{2}{*}{ ETH } & Indeks LQ45 & \multicolumn{2}{c}{ Portofolio } \\
\cline { 5 - 6 } & & & & BTC-LQ45 & ETH-LQ45 \\
\hline Minimum & $-0,17051$ & $-0,26906$ & $-0,05173$ & $-0,08083$ & $-0,14030$ \\
Maximum & 0,25559 & 0,29511 & 0,03725 & 0,12913 & 0,16122 \\
Average & 0,00355 & 0,00450 & 0,00022 & 0,00187 & 0,00239 \\
Std. Dev. & 0,04194 & 0,06017 & 0,00866 & 0,02138 & 0,03059 \\
Beta & $-0,02311$ & 0,14682 & 0,97669 & 0,48241 & 0,55621 \\
\hline
\end{tabular}

Tabel 1, menunjukkan nilai rata-rata return portofolio bitcoin dengan indeks LQ45 sebesar 0,00187 dan portofolio ethereum dengan indeks LQ45 sebesar 0,00239. Standar deviasi portofolio bitcoin dengan indeks LQ45 sebesar 0,02138 dan portofolio ethereum dengan indeks LQ45 sebesar 0,03059. Standar deviasi menyatakan besar kecilnya perubahan return investasi terhadap rata-rata return investasi yang saling berkaitan. Rata-rata return investasi dapat membantu prediksi return masa yang akan datang dan standar deviasi dapat membantu prediksi risiko masa mendatang. Pengukuran standar deviasi mencerminkan total risiko dari investasi.

Perhitungan risiko sistematis (beta) cryptocurrency yang terdiri dari bitcoin dan ethereum dengan indeks LQ45 selama periode penelitian dari Juni 2016 sampai Juni 2019 menunjukkan nilai beta portofolio bitcoin dengan indeks LQ45 sebesar 0,48241 sedangkan ethereum dengan indeks LQ45 sebesar 0,55621 . Beta digunakan sebagai tolak ukur risiko dari investasi. Beta untuk portofolio adalah bernilai 1 . Nilai beta $<1$ maka mempunyai risiko portofolio lebih kecil dari risiko pasar dan sebaliknya portofolio yang mempunyai nilai beta $>1$ maka risiko portofolio lebih besar dari risiko pasar. Jika beta $=1$, maka diharapkan akan memperoleh return ekspektasi lebih besar dari return ekspektasi portofolio pasar (Lakaba, 2018). Tabel 1 menunjukkan bahwa nilai beta pada portofolio cryptocurrency dengan indeks LQ45 < 1 yang berarti risiko portofolio lebih kecil daripada risiko pasar.

Uji Unit Root

Pengujian unit root yang digunakan dalam penelitian ini adalah Augmented Dickery-Fuller (ADF) Test yang merupakan tes unit root untuk menguji stasioner suatu data. Hasil dari Augmented Dickery-Fuller (ADF) Test dapat dilihat pada tabel 2. Dari semua variabel yang digunakan dalam penelitian ini memiliki tingkat probabilitas sebesar 0.0000 . Tabel 2 menunjukkan bahwa data yang digunakan bersifat stasioner sehingga analisis selanjutnya dapat menggunakan teknik GARCH (Robiyanto, 2017). Dengan ketentuan sebagai berikut jika ADF t-statistik > t-critical MacKinnon maka tidak stasioner dan jika ADF t-statistik < t-critical MacKinnon maka stasioner 
Tabel 2. Augmented Dickery-Fuller (ADF) Test

\begin{tabular}{lcccccc}
\hline \multirow{2}{*}{ Variabel } & ADF Test & \multicolumn{2}{c}{ Nilai Kritis MacKinnon } & \multirow{2}{*}{ Prob. } & \multirow{2}{*}{ Kesimpulan } \\
\cline { 3 - 5 } & Statistic & $1 \%$ & $5 \%$ & $10 \%$ & & \\
\hline Bitcoin & -33.74035 & -3.43600 & -2.86392 & -2.56809 & 0.0000 & Stasioner \\
\hline Ethereum & -33.22526 & -3.43600 & -2.86392 & -2.56809 & 0.0000 & Stasioner \\
\hline Indeks LQ45 & -32.51176 & -3.43600 & -2.86392 & -2.56809 & 0.0000 & Stasioner \\
\hline
\end{tabular}

\section{Hasil Analisis GARCH}

Hasil analisis GARCH antara bitcoin dan indeks LQ45 dapat dilihat pada gambar 1 dan gambar 2. Grafik DCC-GARCH antara bitcoin dan indeks LQ45 pada periode Juni 2016 sampai Juni 2019 menunjukkan bahwa adanya korelasi antara bitcoin dan indeks LQ45 berada pada kisaran minus 0,04 sampai minus 0,06. Adanya korelasi rendah menunjukkan bahwa bitcoin dapat dijadikan sebagai aset lindung nilai terhadap aset lain. Pembentukan portofolio antara bitcoin dengan indeks LQ45 dapat menggunakan dynamic portfolio weight yang disajikan pada gambar 2. Rata-rata dynamic portfolio weight berada pada $45,84 \%$ untuk bitcoin dan $50,10 \%$ untuk indeks LQ45.

Dynamic Conditional Correlation Bitcoin-Index LQ45

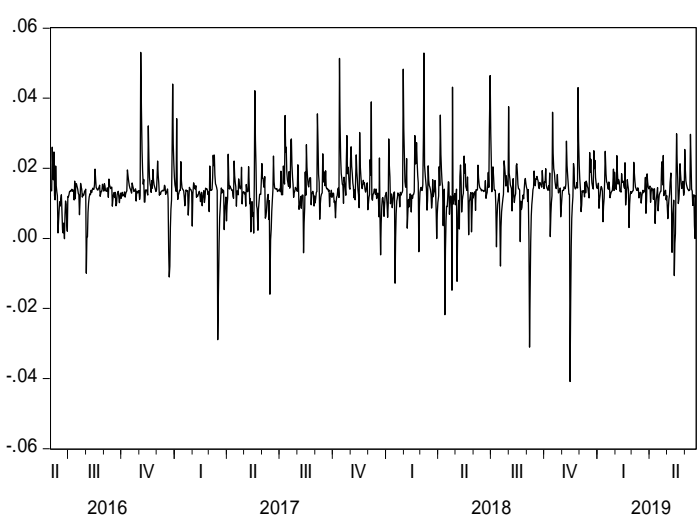

Gambar 1. DCC BTC-LQ45

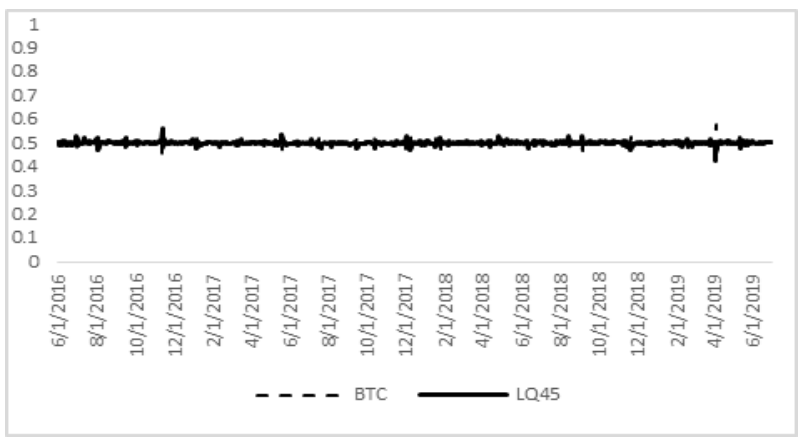

Gambar 2. Dynamic portfolio weight BTCLQ45
Dynamic Conditional Correlation Ethereum-Index LQ45

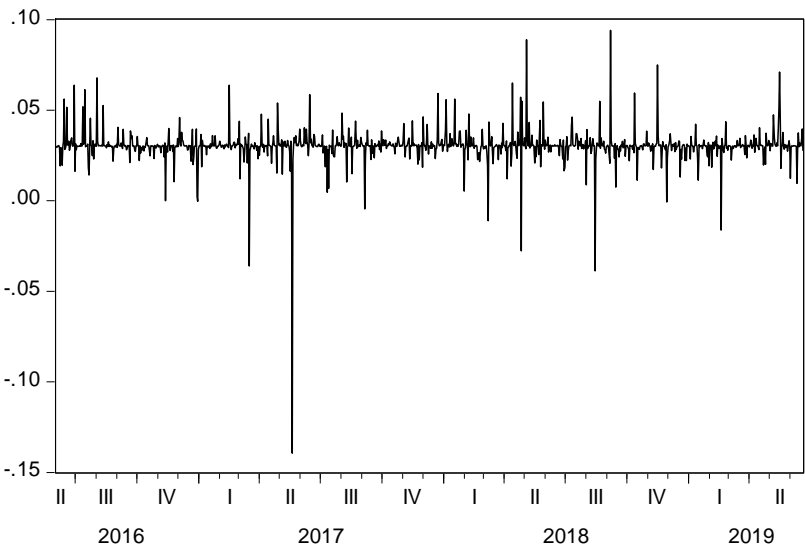

Gambar 3. DCC ETH-LQ45

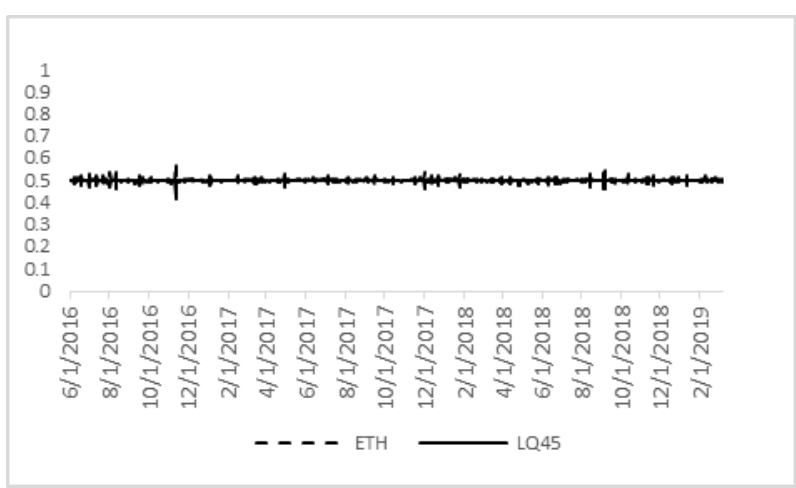

Gambar 4. Dynamic portfolio weight ETHLQ45

Gambar 3 menunjukkan hasil grafik DCC-GARCH antara ethereum dan indeks LQ45 periode Juni 2016 sampai Juni 2019. Korelasi antara ethereum dan indeks LQ45 berada pada kisaran minus 0,15 kemudian pada kuartal kedua tahun 2017 menjadi minus 0,00 . Korelasi yang relatif rendah menunjukkan bahwa ethereum dapat menjadi aset lindung nilai. Pembentukan portofolio antara ethereum dengan indeks indeks LQ45 disajikan pada gambar 4 yang menunjukkan rata-rata dynamic portfolio weight berada pada 49,84\% untuk ethereum dan 50,15\% untuk indeks LQ45. 
Tabel 3. Cryptocurrency Hedging Effectiveness and Optimal Hedge Ratio

\begin{tabular}{lcc}
\hline & Hedging Effectiveness & Optimal Hedge Ratio \\
\cline { 2 - 3 } BTC-LQ45 & 0,7400 & 0,0137 \\
\hline ETH-LQ45 & 0,7415 & 0,0303 \\
\hline & & Sumber : Investing, Data diolah
\end{tabular}

Hedging Effectiveness (HE) pada tabel 3 merupakan hasil dari perhitungan nilai $\mathrm{HE}$ yang ditetapkan pada portofolio dinamis cryptocurrency dengan indeks LQ45, nilai HE bitcoin sebesar 0,74 atau $74 \%$ yang menunjukkan bahwa dengan melibatkan bitcoin ke dalam indeks LQ45 dapat mengurangi risiko portofolio menjadi $74 \%$. Demikian juga pada nilai $\mathrm{HE}$ ethereum sebesar 0,7415 atau $74,15 \%$ menunjukkan dengan melibatkan ethereum ke dalam indeks
LQ45 dapat mengurangi risiko portofolio menjadi $74,15 \%$. Indeks HE yang memiliki nilai semakin tinggi akan menunjukkan efektivitas lindung nilai yang baik. Dalam hal ini ethereum memiliki efektivitas lindung nilai yang lebih tinggi jika dibandingkan dengan bitcoin sehingga ethereum lebih baik dalam melakukan hedge. Nilai Optimal Hedge Ratio BTC-LQ45 adalah 0,0137, sedangkan nilai Optimal Hedge Ratio ETH-LQ45 adalah 0,0303 .

Tabel 4. Hasil Pengukuran Kinerja Portofolio Dinamis Cryptocurrency dengan Indeks LQ45

\begin{tabular}{|c|c|c|c|c|c|}
\hline & \multicolumn{3}{|c|}{ Unhedged Portfolio } & \multicolumn{2}{|c|}{ Cryptocurrency Hedged Portfolio } \\
\hline & Bitcoin & Ethereum & Indeks LQ45 & BTC-LQ45 & ETH-LQ45 \\
\hline Sharpe & 0,0813 & 0,0725 & 0,0090 & 0,0810 & 0,0736 \\
\hline Treynor & $-0,1476$ & 0,0297 & 0,0000 & 0,0035 & 0,0041 \\
\hline Jensen & 0,0034 & 0,0043 & $-0,0001$ & 0,0017 & 0,0022 \\
\hline Sortino & 0,1078 & 0,0555 & 0,0196 & 0,1154 & 0,0560 \\
\hline
\end{tabular}

Sumber : Investing, Data diolah

\section{Kinerja Portofolio dengan Sharpe Index}

Pengukuran kinerja portofolio dengan Sharpe Index menekan pada standar deviasi atau risiko total. Sharpe Index pada tabel 4, menunjukkan nilai indeks LQ45 sebesar 0,0090, portofolio bitcoin dengan indeks LQ45 sebesar 0,0810 dan portofolio ethereum dengan indeks LQ45 sebesar 0,0736. Sharpe Index yang memiliki nilai positif atau semakin besar maka akan menunjukkan kinerja portofolio yang semakin baik. Pada periode pengamatan Juni 2016 sampai Juni 2019, nilai Sharpe Index pada portofolio cryptocurrency yang terdiri dari ethereum dan indeks LQ45 menunjukkan bahwa ethereum memiliki yang kinerja lebih baik jika dibandingkan dengan risiko total.

\section{Kinerja Portofolio dengan Treynor Index}

Hasil pengukuran kinerja portofolio Treynor Index menggunakan return rata-rata dan menggunakan nilai beta sebagai tolak ukur risiko sistematis. Nilai beta pada portofolio telah disajikan pada tabel 1. Jika nilai Treynor Index positif dan semakin besar maka menunjukkan kinerja portofolio semakin baik. Pada tabel 4 dapat dilihat bahwa nilai pengukuran kinerja portofolio dengan Treynor Index pada portofolio bitcoin dengan indeks LQ45 sebesar 0,0035 dan portofolio ethereum dan indeks LQ45 sebesar 0,0041. Pengukuran kinerja portofolio dengan Treynor Index menunjukkan bahwa bitcoin memiliki kinerja yang lebih baik jika dibandingkan dengan risiko sistematis.

\section{Kinerja Portofolio dengan Jensen Index}

Hasil perhitungan dengan Jensen Index pada periode Juni 2016 sampai Juni 2019 dilihat pada tabel 4. Nilai Jensen Index pada unhedged portfolio indeks LQ45 sebesar minus 0,0001, dan untuk hedged portfolio antara bitcoin dan indeks LQ45 berada pada nilai 0,0017 sedangkan portofolio antara ethereum dan indeks LQ 45 memiliki nilai sebesar 0,0022 , dari perbandingan tersebut dapat dilihat dengan menggunakan Jensen Index, tidak ada yang portofolio lebih baik tetapi secara umum lebih baik portofolionya hanya dibandingkan dengan indeks LQ45. Jensen Index yang memiliki nilai positif dan semakin tinggi akan menunjukkan kinerja portofolio yang semakin baik.

\section{Kinerja Portofolio dengan Sortino Ratio}

Sortino Ratio merupakan rasio yang berfokus pada suatu risiko menguntungkan yang didasarkan pada tingkat bebas risiko. Sortino Ratio dengan nilai positif dan semakin tinggi menunjukkan kinerja portofolio akan semakin baik. Berdasarkan tabel 4, perbandingan nilai pengukuran kinerja 
portofolio dengan Sortino Ratio menunjukkan bahwa nilai BTC-LQ45 sebesar 0,1154 dan ETH-LQ45 sebesar 0,0560 yang berarti keduanya memiliki kinerja yang lebih baik. Pada hedged portfolio kedua aset ini lebih baik jika dibandingkan dengan indeks LQ45 saja dan dengan memasukkan cryptocurrency dalam portofolio akan menghasilkan kinerja portofolio yang lebih baik

\section{PENUTUP}

Tujuan dari penelitian ini adalah untuk menganalisis kinerja portofolio yang dibentuk antara cryptocurrency dengan indeks LQ 45 memiliki kinerja yang lebih baik daripada portofolio yang hanya dibentuk dari indeks LQ45 saja. Dengan menggunakan hasil model DCC-GARCH, penelitian ini menyimpulkan bahwa cryptocurrency yang terdiri dari bitcoin dan ethereum memiliki korelasi negatif dengan indeks LQ45 sehingga adanya korelasi ini menunjukkan bahwa cryptocurrency dapat dijadikan sebagai aset lindung nilai terhadap aset lain. Berdasarkan Hedging Effectiveness (HE) menunjukan bahwa dengan melibatkan cryptocurrency ke dalam indeks LQ45 dapat mengurangi risiko dari portofolio yang telah dibentuk. Ethereum memiliki aset lindung nilai aset yang lebih tinggi dari bitcoin, hal ini menunjukkan bahwa ethereum lebih baik dalam melakukan hedge.

Hasil pengukuran kinerja portofolio dengan menggunakan Sharpe index menunjukkan bahwa ethereum memiliki kinerja yang lebih baik jika dibandingkan dengan risiko total. Untuk pengukuran dengan Treynors index menunjukkan bahwa bitcoin memiliki kinerja yang lebih baik jika dibandingkan dengan risiko sistematis dan berdasarkan pengukuran Jensen Index menunjukkan bahwa tidak ada kinerja portofolio yang lebih baik tetapi secara keseluruhan lebih baik kinerja dari portofolio hanya dibandingkan dengan indeks LQ45 saja sedangkan hasil pengukuran kinerja portofolio dengan menggunakan Sortino Ratio menunjukkan bahwa bitcoin dan ethereum sama-sama memiliki kinerja yang lebih baik dan dengan memasukkan cryptocurrency ke dalam portofolio akan menunjukkan kinerja portofolio yang lebih baik.

Dalam penelitian ini untuk mengukur kinerja portofolio hanya berfokus pada cryptocurrency yang terdiri dari dua aset saja yaitu bitcoin dan ethereum sedangkan untuk membentuk portofolio yang lebih baik dapat menggunakan lebih dari aset tersebut. Selain itu, keterbatasan dalam penelitian ini yaitu terletak pada periode pengamatan yang masih relatif pendek karena keberadaan cryptocurrency yang masuk ke Indonesia terbilang masih baru. Oleh karena itu, untuk melengkapi hasil dari penelitian ini disarankan agar penelitian lebih lanjut dapat melakukan kajian lebih khusus dalam mengukur kinerja portofolio dengan menggunakan lebih dari dua aset cryptocurrency ataupun jenis aset lainnya dan perlu melakukan updating data periode terbaru..

\section{DAFTAR PUSTAKA}

Angriana, \& Robiyanto. (2018). Evaluasi Kinerja Saham Bertanggung Jawab Sosial (Studi Pada Saham-Saham yang Masuk Perhitungan Indeks Sri-Kehati). Jurnal Organisasi Dan Manajemen, 14(2), 94-106.

Arouri,Mohamed El Hedi, Jouini, J., \& Duc, K. N. (2012). On the impacts of oil price fluctuations on European equity markets : Volatility spillover and hedging effectiveness. Energy Economics, 34(2), 611-617. https://doi.org/10.1016/i.eneco.2011.08.0 $\underline{09}$

Basher, S. A., \& Sadorsky, P. (2015). Hedging emerging market stock prices with oil, gold, VIX, and bonds: A comparison between DCC, ADCC and GO-GARCH. Energy

Economics. https://doi.org/10.1016/j.eneco.2015.1022

Beneki, C., Koulis, A., Kyriazis, N. A., \& Papadamou, S. (2019). Investigating volatility transmission and hedging properties between Bitcoin and Ethereum. Research in International Business and Finance, 48(1), 219-227. https://doi.org/10.1016/j.ribaf.2019.01.001

Bierman, H. (1998). A Utility Approach to the Portfolio Allocation Decision and the Investment Horizon. Portfolio Management, 25(1), 81-87.

Bouri, E., Jalkh, N., Molnar, P., \& Roubaud, D. (2017). Bitcoin for energy commodities before and after the December 2013 crash: diversifier, hedge or safe haven? Applied Economics, 49(50), 5063-5073. https://doi.org/10.1080/00036846.2017.12 $\underline{99102}$ 
Chandra, L., \& Hapsari, Y. D. (2012). Analisis Pembentukan Portofolio Optimal Dengan Menggunakan Model, 1(1), 1-9.

Dahlan, S., Topowijono, \& Z.A, Z. (2012). Penggunaan Single Index Model dalam Analisis Portofolio. Jurnal Administrasi Bisnis (JAB), 6(2), 1-10.

Dyhrberg, A. H. (2016). Bitcoin, gold and the dollar - A GARCH volatility analysis. Finance Research Letters, 16(2), 8592.https://doi.org/10.1016/j.frl.2015.10.00 8.

Eko, U. (2008). Analisis dan Penilaian Kinerja Portofolio Optimal Saham-saham LQ-45. Jurnal Ilmu Administrasi Dan Organisasi, 15(1), 178-187.

Guo, D., Dong, J., \& Wang, K. (2019). Graph structure and statistical properties of Ethereum transaction relationships. Information Sciences, 492(2), 58-71. https://doi.org/10.1016/j.ins.2019.04.013

Hartono, J. (2010). Teori Portofolio dan Analisis Investasi (Edisi Keli). Yogyakarta: BPFE.

Husnan, S. (2003). Dasar-dasar Teori Portofolio dan Analisis Sekuritas. Yogyakarta: Unit Penerbit dan Percetakan AMP YKPN.

Katsiampa, P. (2018). Volatility co-movement between Bitcoin and Ether. Finance Research Letters, 24(2), 1-190 https://doi.org/10.1016/i.frl.2018.10.005

Mensi, W., Lee, Y. J., Al-Yahyaee, K. H., Sensoy, A., \& Yoon, S. M. (2019). Intraday downward/upward multifractality and long memory in Bitcoin and Ethereum markets: An asymmetric multifractal detrended fluctuation analysis. Finance Research Letters, 31 (2), 19-25. https://doi.org/10.1016/i.frl.2019.03.029

Mensi, W., Rehman, M. U., Al-Yahyaee, K. H., Al-Jarrah, I. M. W., \& Kang, S. H. (2019). Time frequency analysis of the commonalities between Bitcoin and major Cryptocurrencies: Portfolio risk management implications. North American Journal of Economics and Finance, $48 \quad$ (1), 283-294. https://doi.org/10.1016/j.najef.2019.02.01 3
Nugroho, R. Y. Y. (2011). Jurnal Investasi Dampak Fluktuasi Dinamis Makro Ekonomi , IHSG , dan SIBOR terhadap Jakarta Islamic Index, 7(1), 76-89.

Oktaviani, B. N., \& Wijayanto, A. (2016). Aplikasi Single Index Model dalam Pembentukan Portofolio Optimal Saham LQ45 dan Jakarta Islamic Index. Management Analysis Journal, 5(3), 189202.

https://doi.org/10.15294/maj.v5i3.10651

Pal, D., \& Mitra, S. K. (2019). Hedging bitcoin with other financial assets. Finance Research Letters, 4(1), 1-90. https://doi.org/10.1016/i.frl.2019.03.034

Prihanto, M. P. S., Atahau, A. D. R., \& Robiyanto, R. (2018). Portofolio Kelas Cross-Aset antara Emas dan Saham di Indonesia Mesakh Prihanto Surya Putra, 10(1), 69-81.

Priyatna, Y., \& Sukono, F. (2003). Optimasi Portofolio Investasi dengan Menggunakan Model Markowitz, 6(1), 118.

Puspitasari, R., \& Pramesti, D. (2011). Analisis Resiko dan Tingkat Pengembalian Saham Terhadap Portofolio Optimal Saham (Studi Kasus pada 8 saham dari LQ-45 ), 11(2), 17-21.

Rini, S., Handayani, S. R., Hidayat, R., Administrasi, F. I., Brawijaya, U., \& Sharpe, M. (2012). Evaluasi Kinerja Portofolio dengan Menggunakan Model Sharpe, 2(1), 1-8.

Robiyanto, R., Ernayani, R., \& Susiswo Ismail, R. (2019). Formulation of a dynamic portfolio with stocks and fixed-income instruments in the Indonesian capital market. Organizations and Markets in Emerging Economies, 10(1), 132-146. https://doi.org/10.15388/omee. 2019. $\underline{10.00007}$

Robiyanto, R., Wahyudi, S., \& Pangestuti, I. R. D. (2017). The Volatility-Variability Hypotheses Testing and Hedging Effectiveness of Precious Metals for the Indonesian and Malaysian Capital Markets. Gadjah Mada International Journal of Business, 19(2), 167. https://doi.org/10.22146/gamaijb.26260 
Santosa, M., \& Sjam, A. A. (2012). Penilaian kinerja produk reksadana dengan menggunakan metode perhitungan. Jurnal Manajemen, 12(1), 63-76.

Tandelilin, E. (2001). Analisis Investasi dan Manajemen Portofolio (Edisi Pert). Yogyakarta: BPFE.

Tuerah, C. (2013). Perbandingan Kinerja Saham LQ45 Tahun 2012 Menggunakan Metode Jensen, Sharpe dan Treynor. Jurnal Riset Ekonomi, Manajemen, Bisnis Dan Akuntansi, 1(4), 1444-1457.

Ukhriyawati, C. F., Ratnawati, T., \& Riyadi, S. (2017). The Influence of Asset Structure, Capital Structure, Risk Management and Good Corporate Governance on Financial Performance and Value of The Firm through Earnings and Free Cash Flow As An Intervening Variable in Banking Companies Listed in Indonesia Stock.
International Journal of Business and Management, 12(8), 249-260. https://doi.org/10.5539/ijbm.v12n8p249

Wibowo, W. M. (2014). Penerapan Model Indeks Tunggal untuk Menetapkan Komposisi Portofolio Optimal Studi Pada Saham-Saham LQ 45 yang Listing di Bursa Efek Indonesia BEl) Tahun 20102012. Jurnal Administrasi Bisnis, 9(1), 119.

Winarno, W. W. (2007). Analisis Ekonometrika dan Statistika dengan Eviews. Yogyakarta: Unit Penerbit dan Percetakan Sekolah Tinggi IImu Manajemen YKPN.

Yuniarti, S. (2010). Pembentukan Portofolio Optimal Saham - Saham Perbankan Dengan Menggunakan. Jurnal Keuangan Dan Perbankan, 14(3), 459-466. 